\title{
Acute Amphetamine Exposure Selectively Desensitizes $\kappa$-Opioid Receptors in the Nucleus Accumbens
}

\author{
Yan-fang Xia', Li He', Jennifer L Whistler ${ }^{1,2}$ and Gregory O Hjelmstad*,1,2 \\ 'Ernest Gallo Clinic and Research Center, University of California, San Francisco, CA, USA; '² Department of Neurology and Wheeler Center for the \\ Neurobiology of Addiction, University of California, San Francisco, CA, USA
}

\begin{abstract}
In the present study, we investigated the effects of psychostimulant exposure on $\kappa$-opioid peptide (KOP) receptor signaling in the rat mesolimbic system. A single subcutaneous (s.c.) injection of amphetamine $(2.5 \mathrm{mg} / \mathrm{kg})$ reduced the KOP receptor-mediated inhibition of glutamate release in the nucleus accumbens shell, as a consequence of KOP receptor desensitization. This effect was blocked by dopamine (DA) receptor antagonists or the nonselective opioid antagonist, naltrexone (I mg/kg, s.c.), and mimicked by the KOP receptor agonists $U 69593(0.32 \mathrm{mg} / \mathrm{kg}$, s.c.) and dynorphin ( $\mathrm{I} \mu \mathrm{M})$, indicating that an amphetamine-induced release of dynorphin is producing a long-lasting desensitization of the KOP receptor. Despite the fact that amphetamine also increases dynorphin release in the ventral tegmental area (VTA), KOP receptor function in this region was not affected by amphetamine; there was no difference in the KOP receptor-mediated change in firing rate or resting membrane potential measured in VTA neurons from saline- or amphetaminetreated animals. This study demonstrates that amphetamine can produce regionally selective adaptations in KOP receptor signaling, which may, in turn, alter the effects of subsequent drug exposure.

Neuropsychopharmacology (2008) 33, 892-900; doi: I0. I038/sj.npp. I 301463; published online 6 June 2007
\end{abstract}

Keywords: amphetamine; $\kappa$-opioid; nucleus accumbens; ventral tegmental area; desensitization; addiction

\section{INTRODUCTION}

The nucleus accumbens (NAc) and ventral tegmental area (VTA) are two important components of the neural circuitry underlying motivation and reinforcement (Everitt and Wolf, 2002; Kelley et al, 2005), and long-lasting changes in these nuclei are thought to underlie drug addiction (Nestler, 2004). The NAc receives a predominantly dopaminergic projection from the VTA (Swanson, 1982). Likewise, a subset of the GABAergic medium spiny neuron (MSNs) in the NAc project back to the VTA (Conrad and Pfaff, 1976; Phillipson, 1979). These VTA-projecting MSNs express the neuropeptides substance $\mathrm{P}$, which targets the neurokinin 1 (NK1) receptor, and dynorphin, which targets the $\kappa$-opioid peptide (KOP) receptor (Fallon et al, 1985; Anderson and Reiner, 1990). These neuropeptides are not only released in the VTA, but are also presumably released within the NAc itself, as the axons of MSNs collateralize extensively within the nucleus (Chang and Kitai, 1985).

KOP receptors are distributed throughout this circuit and clearly influence reward-related behaviors (Shippenberg

\footnotetext{
* Correspondence: Dr GO Hjelmstad, Ernest Gallo Clinic and Research Center, 5858 Horton Street, Suite 200, Emeryville, CA 94608, USA, Tel: + | 510985 3927, Fax: + | 5109853101 ,

E-mail: gregh@gallo.ucsf.edu

Received I4 February 2007; revised 23 April 2007; accepted 26 April 2007
}

and Elmer, 1998; Todtenkopf et al, 2004). For example, KOP receptor agonists injected into either the VTA or the NAc produce conditioned place aversion (Bals-Kubik et al, 1993). In the rat VTA, KOP receptors directly hyperpolarize a subset of dopamine (DA) neurons (Margolis et al, 2003), specifically those that project to the prefrontal cortex (Margolis et al, 2006). Within the NAc, KOP receptor agonists inhibit the release of glutamate (Yuan et al, 1992; Hjelmstad and Fields, 2001, 2003). DA signaling in the prefrontal cortex and glutamate signaling in the NAc have both been implicated in drug relapse (Cornish and Kalivas, 2000; McFarland and Kalivas, 2001; McFarland et al, 2003). Thus, the localization as well as behavioral actions of KOP receptors makes them an inviting therapeutic target for the treatment of addiction.

In addition to altering influencing behavioral responses to psychostimulants, the KOP system shows adaptations following psychostimulant administration (Shippenberg et al, 2001). For example, following a single injection of amphetamine, dynorphin mRNA levels are increased, while KOP receptor binding is decreased (Turchan et al, 1998). In light of data showing that even a single injection of amphetamine can produce behavioral sensitization in rats (Vanderschuren et al, 1999), these changes in KOP signaling may have profound effects on behavior. Thus, determining the functional implications of this plasticity is crucial to our understanding of the role of KOPs in addiction. Here, we investigated the effect of in vivo administration of 
amphetamine on KOP receptor function in both the NAc and the VTA. We find that amphetamine treatment produces a long-lasting functional downregulation of the KOP receptor on glutamate terminals in the NAc shell but has no impact on postsynaptic KOP receptor function in the VTA. Furthermore, we show that this decrease in function in the NAc is due to desensitization of the KOP receptor.

\section{MATERIALS AND METHODS}

\section{Slice Preparation}

All animal procedures were in accordance with protocols approved by the Ernest Gallo Clinic and Research Center's institutional animal care and use committee. Three- to fourweek old male Sprague-Dawley rats were given subcutaneous (s.c.) D-amphetamine sulfate $(2.5 \mathrm{mg} / \mathrm{kg}$ in saline), U69593 $(0.32 \mathrm{mg} / \mathrm{kg})$, or saline $(0.9 \% \mathrm{NaCl})$ injections and returned to their cage for $2 \mathrm{~h}$ or 1-5 days (for the time course analysis). Flupenthixol dihydrochloride $(0.5 \mathrm{mg} / \mathrm{kg})$, $\mathrm{SCH}-23390$ hydrochloride $(0.1 \mathrm{mg} / \mathrm{kg})$, and naltrexone hydrochloride $(1 \mathrm{mg} / \mathrm{kg})$ were diluted in saline and administered s.c. $15 \mathrm{~min}$ before the amphetamine injection. While naltrexone is most selective for $\mu$-opioid peptide (MOP) receptors, it also binds KOP receptors in the lownanomolar range (Goldstein and Naidu, 1989).

To prepare slices, animals were anesthetized with isoflurane, decapitated, and the brain removed and placed into an ice-cold Ringer's solution $\left(\sim 3^{\circ} \mathrm{C}\right)$ containing (in mM) $119 \mathrm{NaCl}, 2.5 \mathrm{KCl}, 1.3 \mathrm{MgSO}_{4}, 1.0 \mathrm{NaH}_{2} \mathrm{PO}_{4}, 2.5 \mathrm{CaCl}_{2}$, $26.2 \mathrm{NaHCO}_{3}$, and 11 glucose saturated with $95 \% \mathrm{O}_{2} / 5 \%$ $\mathrm{CO}_{2}$. Coronal slices $(350 \mu \mathrm{m}$ thick) containing the NAc, or $150 \mu \mathrm{m}$ thick horizontal slices containing the VTA were cut using a vibratome (Leica Instruments, Germany). Slices were submerged in Ringer's solution and allowed to recover for $>1 \mathrm{~h}$ at $34^{\circ} \mathrm{C}$.

\section{Electrophysiology}

Individual slices were transferred to an Olympus upright microscope with differential interference contrast optics and infrared illumination. Extracellular field or whole-cell patch-clamp recordings were made at $28^{\circ} \mathrm{C}$. Picrotoxin $(100 \mu \mathrm{M})$ was added to the Ringer's solution to block $\mathrm{GABA}_{\mathrm{A}}$ receptor-mediated inhibitory postsynaptic potentials. Field recordings were made by placing a 3-5 M $\Omega$ electrode filled with Ringer's solution into the medial shell of the NAc, which can be visually distinguished from the neighboring core region in a coronal slice. Whole-cell voltage-clamp recordings from NAc MSNs were made using 2.5-4 $\mathrm{M} \Omega$ pipettes containing (in $\mathrm{mM}$ ) $123 \mathrm{Cs}$-gluconate, 10 4-(2-hydroxyethyl)-1-piperazineethanesulfonic acid, 0.2 ethylene glycol tetraacetic acid (EGTA), $8 \mathrm{NaCl}, 2 \mathrm{MgATP}$, $0.3 \mathrm{Na}_{3} \mathrm{GTP}$ ( $\mathrm{pH}$ 7.2, osmolarity adjusted to 280). Cells were identified as MSNs by their appearance and by their relatively hyperpolarized resting potential. Excitatory postsynaptic field potentials (fEPSPs) and excitatory postsynaptic currents (EPSCs) were evoked $(0.067 \mathrm{~Hz})$ with a bipolar-stimulating electrode placed along the dorsal edge of the NAc.

VTA whole-cell recordings were made using an internal solution where the Cs-gluconate was replaced with
K-gluconate. $I_{\mathrm{h}}$ currents were recorded in voltage clamp, stepping the neuron from -60 to $-40,-50,-70,-80,-90$, $-100,-110$, and $-120 \mathrm{mV}$. Firing rate and membrane potential were monitored in the current-clamp $(I=0)$ mode.

All recordings were made using a Multiclamp 700A (Axon Instruments) amplifier and were filtered at $2 \mathrm{kHz}$ and collected at $5 \mathrm{kHz}$ using Igor Pro (Wavemetrics Inc., Lake Oswego, OR). Series resistance was monitored online by measuring the peak of the capacitance transient in response to a $-4 \mathrm{mV}$ voltage step applied before each stimulus. Amplitudes were calculated by comparing a $2 \mathrm{~ms}$ period at the peak of the response and a similar period just before the stimulus artifact. Firing rates were analyzed by computing the instantaneous firing rate (calculated as the inverse of the interspike interval after each action potential) and binned into $30 \mathrm{~s}$ bins for statistical analysis or $5 \mathrm{~s}$ bins for display purposes. For each VTA neuron, significance was determined comparing the last $3 \mathrm{~min}$ of baseline with the last 3 min of drug application. Unless otherwise noted, statistical analyses were performed using the Student's $t$-test, and significance was defined at $p<0.05$. Results are presented as means \pm SEM.

All drugs were applied by bath perfusion. Stock solutions were made and diluted immediately before application. U69593 was mixed in 50\% ethanol at a concentration of $10 \mathrm{mM}$; nor-binaltorphimine (nor-BNI), dynorphin, and DAMGO were diluted in $\mathrm{H}_{2} \mathrm{O}$ and picrotoxin was mixed in dimethyl sulfoxide. Chemicals were obtained from Sigma Chemical (St Louis, MO) or Tocris (Ballwin, MO).

\section{Western Blot}

VTA slices or NAc tissue blocks were prepared in artificial cerebrospinal fluid as described above. Tissue was placed in ice-cold $50 \mathrm{mM}$ Tris- $\mathrm{HCl}$ ( $\mathrm{pH} 7.4)$, with protease inhibitors and homogenized with a Polytron Homogenizer. The homogenized tissue was centrifuged at $30000 \mathrm{~g}$ for $20 \mathrm{~min}$ at $4{ }^{\circ} \mathrm{C}$, resuspended in same buffer and recentrifuged at $30000 \mathrm{~g}$ for $20 \mathrm{~min}$. The pellets were resuspended and stored at $-80^{\circ} \mathrm{C}$ until use.

Membrane proteins $(20 \mu \mathrm{g} / \mathrm{lane})$ were solubilized by boiling in $2 \%$ sodium dodecyl sulfate containing $50 \mathrm{mM}$ dithiothreitol for $10 \mathrm{~min}$ and were subjected to $4-12 \%$ NuPAGE gel and transferred to polyvinylidene difluoride membranes. The membranes were incubated in blocking buffer (5\% nonfat dry milk, $20 \mathrm{mM}$ Tris- $\mathrm{HCl}, 150 \mathrm{mM} \mathrm{NaCl}$, $0.1 \%$ Tween $20, \mathrm{pH} 7.5$ ) for $1 \mathrm{~h}$ at room temperature (RT) and then incubated in blocking buffer with a polyclonal anti-KOP receptor antibody (Santa Cruz Biotechnology, Santa Cruz, CA; 1:2000 dilution) overnight at $4{ }^{\circ} \mathrm{C}$. The membrane was washed multiple times in the $20 \mathrm{mM}$ Tris-HCl, $150 \mathrm{mM} \mathrm{NaCl}, 0.1 \%$ Tween 20 buffer, and then incubated in horseradish peroxidase-conjugated goat antirabbit antibody (Invitrogen, Carlesbad, CA; 1:5000 dilution) for $2 \mathrm{~h}$ at RT. The membrane was again washed multiple times in $20 \mathrm{mM}$ Tris- $\mathrm{HCl}, 150 \mathrm{mM} \mathrm{NaCl}, 0.1 \%$ Tween 20 buffer, and visualized with enhanced chemiluminescence (Amersham Biosciences, Piscataway, NJ). Western blots were quantified using densitometry normalized to $\beta$-actin levels. 


\section{GTP $\gamma S$ Binding}

$\left[{ }^{35} \mathrm{~S}\right]-\mathrm{GTP} \gamma \mathrm{S}(1250 \mathrm{Ci} / \mathrm{mmol})$ was purchased from PerkinElmer Life Science (Boston, MA). For $\left[{ }^{35} \mathrm{~S}\right] \mathrm{GTP} \gamma \mathrm{S}$ binding in membranes, brain regions were dissected on ice. Tissue samples were homogenized with Teflon homogenizer on ice in membrane buffer $\left(50 \mathrm{mM}\right.$ Tris- $\mathrm{HCl}, 3 \mathrm{mM} \mathrm{MgCl}_{2}, 1 \mathrm{mM}$ EGTA, pH 7.4) and centrifuged at $30000 \mathrm{~g}$ for $20 \mathrm{~min}$ at $4{ }^{\circ} \mathrm{C}$. Pellets were suspended in membrane buffer and centrifuged again under identical conditions. After the second centrifugation, pellets were homogenized in assay buffer $(50 \mathrm{mM}$ Tris- $\mathrm{HCl}, 3 \mathrm{mM} \mathrm{MgCl}_{2}, 0.2 \mathrm{mM}$ EGTA, $100 \mathrm{mM} \mathrm{NaCl}, \mathrm{pH}$ 7.4). Concentration effect curves of $\left[{ }^{35} \mathrm{~S}\right] \mathrm{GTP} \gamma \mathrm{S}$ binding included 30-3000 nM dynorphin, $30 \mu \mathrm{M}$ NaGDP, $0.05 \mathrm{nM}$ $\left[{ }^{35} \mathrm{~S}\right] \mathrm{GTP} \gamma \mathrm{S}, 3 \mu \mathrm{g}$ protein and assay buffer in a final volume of $200 \mu \mathrm{l}$ using 96-well cell culture plates. Assays were incubated at $\mathrm{RT}$ for $1.5 \mathrm{~h}$. Reactions were terminated by transferring to 96-well Unifil plate GF/B glass fiber filters with rapid filtration under vacuum followed by 3 washes with $200 \mu \mathrm{l}$ cold $50 \mathrm{mM}$ Tris-HCl buffer ( $\mathrm{pH}$ 7.4). Bound radioactivity was determined by liquid scintillation spectrophotometry at $95 \%$ efficiency for $\left[{ }^{35} \mathrm{~S}\right]$ after overnight extraction of the filters in $40 \mu \mathrm{l}$ Microscint scintillation fluid. Data are reported as mean \pm standard error of four separate experiments with each performed in triplicate. Percent stimulation is defined as ((net stimulated binding - basal binding)/basal binding) $\times 100$. Nonlinear regression analysis of concentration effect curves was performed by Prism (GraphPad Software Inc., San Diego, CA) that determined $\mathrm{EC}_{50}$ values.

\section{RESULTS}

To investigate the effect of amphetamine on KOP receptor function, we initially compared the effects of the KOP receptor agonist U69593 on fEPSPs in the NAc shell in slices prepared from amphetamine- and saline-treated rats. In slices cut $2 \mathrm{~h}$ following a saline injection, U69593 $(1 \mu \mathrm{M})$ inhibited the amplitude of the fEPSP $(23.6 \pm 5.9 \%, n=6$, Figure $1 \mathrm{a}$ and $\mathrm{b})$ similar to that seen in naive tissue (Hjelmstad and Fields, 2001). This KOP receptor-mediated inhibition does not readily reverse following removal of the agonist (Hjelmstad and Fields, 2001), however it was completely reversed following application of the KOP receptor selective antagonist nor-BNI (100 nM). In slices prepared from amphetamine-treated rats, the inhibition produced by U69593 was significantly smaller (Figure 1a and $\mathrm{b}$ ): the average inhibition was reduced to $6.4 \pm 2.9 \%$ ( $n=8, p<0.05$ compared to the saline-treated group). This change in the KOP receptor-mediated inhibition was not due to a change in the IC50 for U69593 $(0.91 \mu \mathrm{M}$ in amphetamine-treated animal compared to $0.64 \mu \mathrm{M}$ in saline-treated animals, Figure 1c) and occurred even in response to saturating doses of U69593. Moreover, the change in inhibition was also observed with the KOP receptor agonist dynorphin A $(500 \mathrm{nM} ; 6.5 \pm 2.2 \%$ for amphetamine-treated group compared to $18.1 \pm 3 \%$ for saline-treated group, $p<0.05$, Figure 1c).

To investigate the time course of this effect, slices were cut $24 \mathrm{~h}$ or 5 days following administration of amphetamine or saline and compared to the $2 \mathrm{~h}$ data. The reduced inhibition was present at both of these time points (Figure 1d): in a
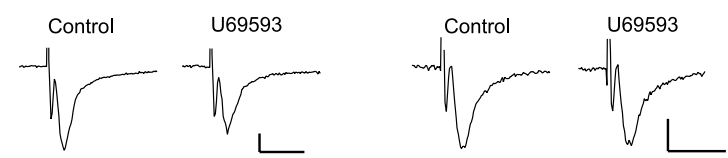

b

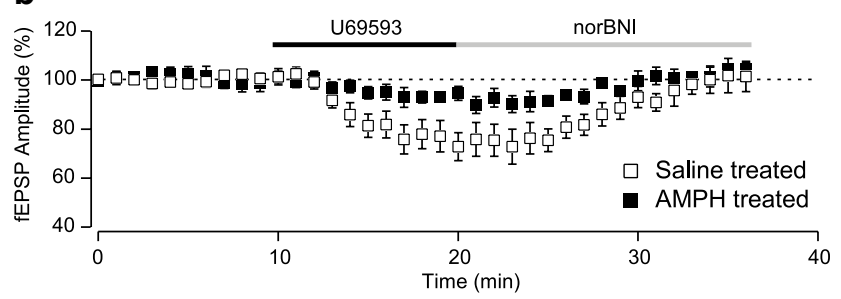

C

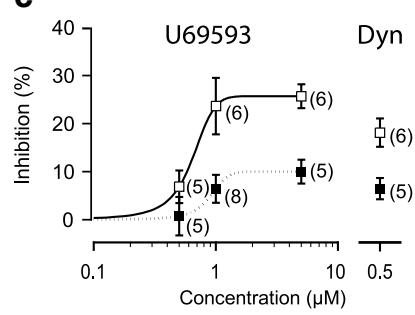

d
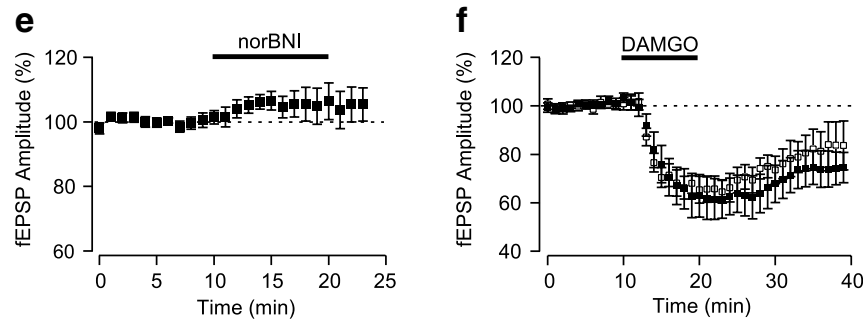

Figure I A single injection of amphetamine reduces the KOP inhibition of glutamate release in the NAc. (a) Average of 10 consecutive fEPSPs during control period and in the presence of $\cup 69593$ from a saline-treated (left) and an amphetamine-treated (AMPH; right) rat. Calibration: $0.2 \mathrm{mV}$, 10 ms. (b) Averaged field recordings comparing the inhibition of U69593 $(\mathrm{I} \mu \mathrm{M})$ on the fEPSP amplitude from slices prepared from saline- and amphetamine-treated rats. (c) Dose-response for U69593-mediated inhibition in slices from amphetamine- and saline-treated rats. Right hand side shows inhibition in response to $500 \mathrm{nM}$ dynorphin (Dyn). Numbers in parentheses show the number of recordings under each condition. (d) Time course of a single amphetamine administration showing the effect lasted for at least 5 days (* $p<0.05$ between saline and amphetamine treatment using a two-factor ANOVA with a Holm-Sidak post hoc test). (e) The selective KOP receptor antagonist, nor-BNI (I00 nM), does not significantly affect fEPSPs in slices from amphetamine-treated rats. (f) The inhibition of fEPSPs by the MOP receptor agonist, DAMGO $(I \mu \mathrm{M})$, is not significantly different between the two groups $(p>0.05)$.

amphetamine-treated animals the inhibition by U69593 was $11.9 \pm 1.7 \%(n=9)$ at $24 \mathrm{~h}$ and $12.1 \pm 1.6 \%(n=11)$ after 5 days, which is significantly less than in the saline-treated group $(23.0 \pm 2.6 \%$ for $24 \mathrm{~h}, n=8 ; 25.1 \pm 5.3 \%, n=5$; $p<0.05$ for each time point).

Because amphetamine has been reported to increase prodynorphin mRNA expression (Wang et al, 1995; Turchan et al, 1998), one possibility for the loss of KOP receptor function is that an increase in the release of endogenous dynorphin within the slice competes with the U69593 response. However, application of nor-BNI alone did not significantly alter the amplitude of the fEPSP in 
amphetamine-treated animals $(105.4 \pm 4.0 \%, n=5 ; p>0.05$, Figure 1e), implying that this is not the case.

MOP receptors are also present in the NAc shell and like KOP receptors, they modulate glutamate release onto MSNs (Yuan et al, 1992; Hjelmstad and Fields, 2001; Hoffman and Lupica, 2001). To investigate whether amphetamine administration also changes MOP receptor function, we tested the effect of the MOP receptor agonist DAMGO on fEPSPs. The inhibition produced by $1 \mu \mathrm{M}$ of DAMGO was not statistically different between the two groups (Figure 1f): DAMGO elicited a $31.1 \pm 4.2 \%$ inhibition in saline-treated animal $(n=5) \quad$ vs $31.6 \pm 7.7 \%$ in amphetamine-treated animal $(n=7, p>0.05)$.

\section{DA-Dependent Increase in Endogenous Dynorphin}

Amphetamine increases extracellular DA. To investigate whether this increase in DA is essential for the loss of KOP receptor function, we injected the nonselective DA receptor antagonist flupenthixol $(0.5 \mathrm{mg} / \mathrm{kg}$, s.c. $) 15 \mathrm{~min}$ before amphetamine administration. In slices prepared from these animals, U69593 produced a $15.6 \pm 2.7 \%(n=9)$ reduction in the amplitude of the fEPSP (Figure 2a). Thus, flupenthixol significantly antagonized the effect of amphetamine $(p<0.05$ compared to amphetamine group, not significant compared to saline group).

We also pretreated the animal with selective D1 receptor antagonist SCH-23390 (0.1 mg/kg, s.c.) $15 \mathrm{~min}$ before amphetamine injection. SCH-23390 also blocked the effect of amphetamine on KOP receptor function. U69593 produced a $20.7 \pm 8.0 \%$ inhibition of the fEPSP $(n=8$, $p<0.05$ compared to amphetamine-treated animal, Figure $2 \mathrm{~b}$ ). These data suggest that the increase of DA levels following the administration of amphetamine activates D1receptors, which is a necessary step for the downregulation of KOP receptor function.

Activation of D1 receptors in the NAc selectively excites substance P/dynorphin-expressing MSNs (Steiner and Gerfen, 1998) and psychostimulants increase dynorphin peptide levels in the striatum (Bustamante et al, 2002). Thus, the reduction in KOP receptor function may reflect agonist-induced desensitization of the receptor caused by the DA-dependent release of dynorphin. To determine the role of endogenous dynorphin release, we tested the effects of the nonselective opioid receptor antagonist naltrexone $(1 \mathrm{mg} / \mathrm{kg}$, s.c.), preadministered before the injection of amphetamine. In slices prepared from these animals, the U69593 inhibition of fEPSPs was similar to those from saline-injected animals (Figure $2 c, 29.6 \pm 5.8 \%, n=9$, $p<0.05$ compared to the amphetamine-treated group), indicating that the amphetamine-mediated inhibition of KOP receptor function acts through an opioid-dependent mechanism.

We next examined whether the effect of naltrexone was through its antagonism of the KOP receptor. We were unable to test whether the KOP receptor-selective antagonist nor-BNI blocks the effects of amphetamine since its actions persist for days to weeks (Horan et al, 1992; Jones and Holtzman, 1992). Instead, we tested whether the systemic administration of a KOP receptor agonist mimics amphetamine's effect. We injected U69593 $(0.32 \mathrm{mg} / \mathrm{kg}$, s.c.) and cut slices after $2 \mathrm{~h}$. U69593 inhibited fEPSPs amplitude
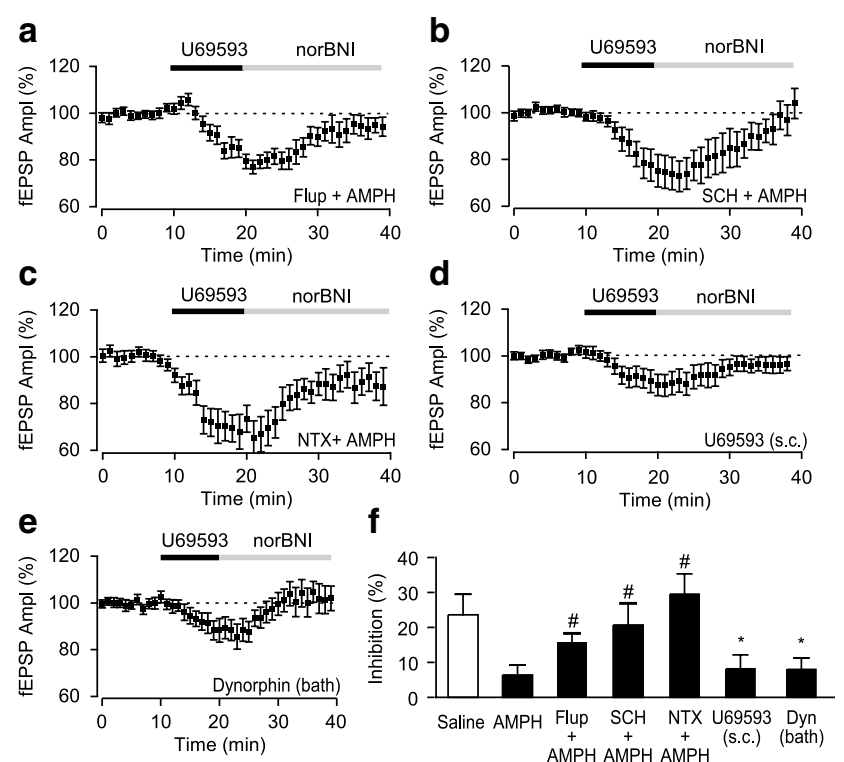

Figure 2 The reduction of KOP receptor function by amphetamine requires DA and can be mediated through enhanced dynorphin release. (a) The diminished KOP receptor-mediated inhibition of glutamate release in amphetamine treated animals is antagonized by systemic administration of flupenthixol $(0.5 \mathrm{mg} / \mathrm{kg}$, s.c.; Flup + AMPH). (b) Administration of $\mathrm{SCH}$ $23390(0.1 \mathrm{mg} / \mathrm{kg}$, s.c.) before amphetamine treatment also blocks the effect on KOP receptor function (SCH $+\mathrm{AMPH})$. (c) Administration of naltrexone (I mg/kg, s.c.) before amphetamine treatment blocks the effect on KOP receptors (NTX + AMPH). (d) Systemic administration of U69593 $(0.32 \mathrm{mg} / \mathrm{kg}$, s.c.) mimics the effects of amphetamine in reducing $\mathrm{KOP}$ receptor function. (e) Incubating slices in dynorphin (500 nM) for $30 \mathrm{~min}$ mimics also the effects of amphetamine administration. ( $f$ ) Summary of the U69593 inhibition of fEPSPs in slices obtained from animals administered with saline, amphetamine, amphetamine coadministered with flupenthixol, $\mathrm{SCH}-23390$ or naltrexone, systemic U69593, or bath incubation of dynorphin ( $p<0.05$ compared to amphetamine-treated group; ${ }^{*} p<0.05$ compared to saline-treated group).

by only $8.2 \pm 4.0 \%$ in slices prepared from these animals ( $n=13, \quad p<0.05$ compared to saline-treated group; Figure 2d). Furthermore, incubating NAc slices prepared from naive rats with dynorphin $(500 \mathrm{nM}$ for $30 \mathrm{~min}$ and then washed with regular Ringer's solution for at least $1 \mathrm{~h}$ ) similarly reduced the magnitude of the KOP receptor inhibition $(8 \pm 3.3 \%, n=10$, Figure $2 \mathrm{e})$.

\section{KOP Receptor Function in the VTA}

Substance P/dynorphin-containing MSNs in the NAc shell project to the VTA (Lu et al, 1998) and psychostimulant administration also increases dynorphin peptide levels in the midbrain (You et al, 1994; Bustamante et al, 2002). Therefore, we investigated whether amphetamine alters KOP receptor function in the VTA. To test this, currentclamp recordings were made from $I_{\mathrm{h}}$-expressing VTA neurons from saline- and amphetamine-treated rats. We found no differences in the responses of VTA neurons to KOP receptor agonists in these two groups. Seven of ten neurons $(70 \%)$ from saline-treated rat were inhibited by U69593 (Figure 3a). Of the inhibited neurons, five neurons showed a decrease in their firing rate whereas the other two neurons did not fire spontaneously, but were hyperpolarized by U69593. In amphetamine-treated rats, seven of 

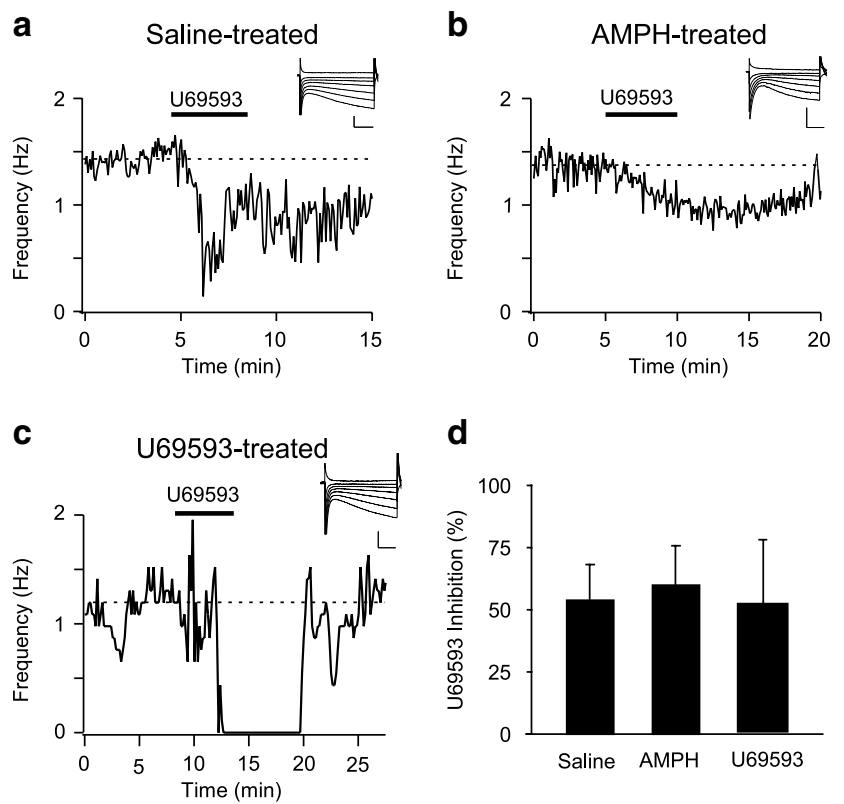

Figure 3 A single dose of amphetamine does not affect KOP receptor function in VTA neurons. (a) A representative recording in a neuron from a saline-treated animal. This neuron expressed an Ih (inset; scale bar, $100 \mathrm{pA}$ and $50 \mathrm{~ms}$ ) and the firing rate was inhibited by $\cup 69593$ (500 nM). (b) A representative neuron from amphetamine-treated animal. This neuron expressed an $/ \mathrm{h}$ and was also inhibited by $500 \mathrm{nM}$ U69593. (c) Summary of neurons inhibited by U69593 in saline- and amphetamine-treated groups. (c) A representative recording from U69593-treated animal. This neuron expressed an $I_{\mathrm{h}}$ and the firing rate was inhibited by U69593. (d) Summary of U69593 inhibition in saline-, amphetamine-, and U69593-treated groups. Bar graph shows the average inhibition in firing rate for KOP receptorsensitive neurons.

eleven neurons (64\%) were inhibited by U69593 with a reduction in firing rate for five neurons and a hyperpolarization in two neurons (Figure $3 \mathrm{~b}$ ). In those cells that were responsive to U69593, there was no difference between the magnitude of the firing rate inhibition between the saline and amphetamine groups (Figure $3 \mathrm{~d}$ ).

One possibility for the difference between the VTA and NAc is that the amphetamine treatment is not increasing dynorphin levels to the same degree in the two brain regions. However, systemic treatment with the KOP receptor agonist U69593, which reduced KOP receptor function in the NAc, did not reduce KOP receptor responses in the VTA: five of nine neurons were inhibited by U69593 (Figure 3c). Three of the five spontaneously firing neurons (60\%) were inhibited by U69593. In those three neurons, U69593 caused $52.2 \pm 25.7 \%$ inhibition in firing rate (Figure 3d). There was no difference among the magnitude of the inhibition compared to saline- and amphetaminetreated group.

\section{Loss of KOP Receptor Function is due to Desensitization}

A previous study found evidence for KOP receptor downregulation in the NAc following psychostimulant treatment (Turchan et al, 1998). Therefore, we asked whether the functional changes we have observed in KOP receptor function in the NAc were due to receptor downregulation. We saw no change in the overall KOP receptor levels
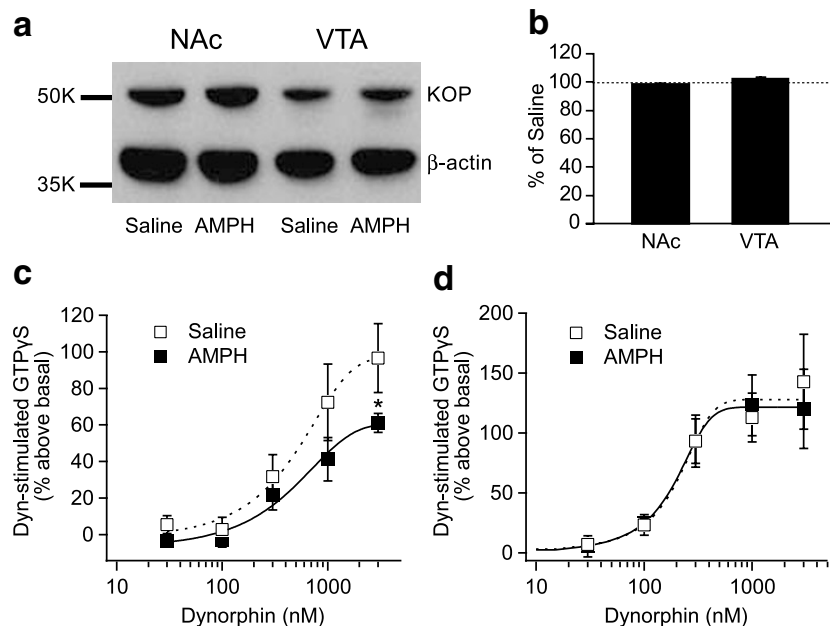

Figure 4 NAc KOP receptors are desensitized following amphetamine treatment. (a) NAc tissue and VTA slices taken from amphetamine- and saline-treated animals exhibited similar expression of KOP receptor. (b) Immunoblots quantified by scanning densitometry showed no significant difference between amphetamine- and saline-treated rats in either the NAc or the VTA. (c) Concentration-effect curves of dynorphin-stimulated $\left.{ }^{35} \mathrm{~S}\right] \mathrm{GTP} \gamma \mathrm{S}$ binding to NAc membranes from rats treated with saline and amphetamine. Data are presented as the mean \pm SEM of four experiments performed in triplicate $(* p<0.05$ compared to saline group). (d) Concentration-effect curves of dynorphin-stimulated $\left[{ }^{35} \mathrm{~S}\right] \mathrm{GTP} \gamma \mathrm{S}$ binding to VTA membranes from saline- vs amphetamine-treated rats.

in either the NAc or the VTA following amphetamine administration (Figure $4 \mathrm{a}$ and $\mathrm{b}$ ).

We next tested whether KOP receptors are desensitized following amphetamine treatment. Using a GTP $\gamma S$ binding assay, we found a significant decrease in dynorphinstimulated GTP $\gamma S$ in membranes prepared from the NAc of amphetamine $v s$ saline-treated rats, with no significant change in the $\mathrm{EC}_{50}$ (Figure 4c). Consistent with our electrophysiological results, we observed no differences in receptor activity in VTA preparations (Figure 4d).

\section{Effects of Amphetamine on Basic Synaptic Properties}

The loss of presynaptic inhibition may be accompanied by other presynaptic changes. To determine whether there were changes in basic synaptic function, we made whole-cell recordings from MSNs and analyzed both the paired-pulse ratio and short-term plasticity in response to trains of stimuli. EPSCs from saline-treated animals showed shortterm depression following a $25 \mathrm{~Hz}$ train. The amplitude of the eighth EPSC was $39.9 \pm 2.5 \%$ of the first ( $n=11$, Figure $5 \mathrm{a}$ and b) similar to the depression seen in naive tissue (Hjelmstad, 2004). In slices from amphetamine-treated rats, the short-term depression was significantly decreased. On average, the eighth EPSC was $55.9 \pm 5.9 \%$ of the first $(n=12$, $p<0.05$, Figure $5 \mathrm{a}$ and $\mathrm{b}$ ). In addition, comparing the amplitudes of the first and second EPSC showed a significant increase in the paired-pulse ratio (saline, $0.87 \pm 0.04$; amphetamine, $1.02 \pm 0.05 \%, p<0.05$, Figure $5 c$ ). Both of these measures of short-term plasticity are consistent with a decrease in the synaptic probability of release. Finally, we tested whether there was a presynaptic change in probability of release by assaying the frequency of spontaneous 

Saline-treated AMPH-treated
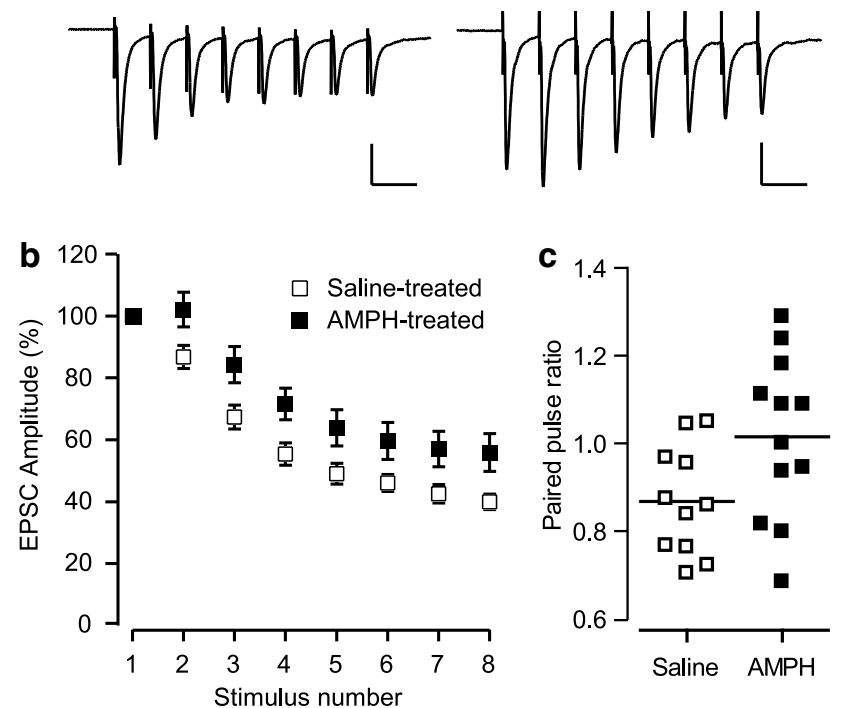

Figure 5 Changes in synaptic short-term plasticity following amphetamine administration. (a) Example of a train of EPSCs (8 stimuli at $25 \mathrm{~Hz}$ ) recorded in a neuron from a saline-treated (left) or amphetamine-treated (AMPH, right) rat (scale bars, left: $200 \mathrm{pA}$ and $50 \mathrm{~ms}$, right: $100 \mathrm{pA}$ and $50 \mathrm{~ms}$ ). (b) Average of responses for all neurons from saline- and amphetamine-treated rats. (c) Paired-pulse ratio (second EPSC/first EPSC) in neurons from saline- and amphetamine-treated rats. Horizontal bar represents the group mean.

miniature postsynaptic conductances (mEPSCs). However, we found no significant difference in the mEPSC frequency in neurons recorded from slices prepared from amphetamine- $v s$ saline-treated animals (data not shown).

\section{DISCUSSION}

Here we show that a single injection of amphetamine causes a long-lasting, regionally selective downregulation of KOP receptor function. This change in function appears to be a consequence of receptor desensitization rather than receptor downregulation. While fEPSPs from saline-treated animals are inhibited by bath application of U69593, this inhibition is attenuated in amphetamine-treated animals. Amphetamine increases extracellular catecholamine levels through reversal of the plasma membrane-associated DA and norepinephrine transporters (Sulzer et al, 2005). Moreover, this increase in DA produces a subsequent increase in dynorphin release, both in the striatum and in the midbrain (You et al, 1994; Bustamante et al, 2002). Our data indicate that this DA-dependent increase in dynorphin mediates the reduction of KOP receptor function. This reduction in KOP function is not due to a change in the IC50 to U69593 and cannot be explained by occlusion of the receptor due to increased levels of endogenous dynorphin in the slice, since nor-BNI has no significant effect on the EPSP amplitude by itself. Finally, this change shows regional specificity: there is no change in the KOP receptormediated hyperpolarization of VTA neurons from amphetamine-treated animals.

Our data indicate that the loss of KOP receptor function in the NAc is caused by a long-lasting desensitization of the receptor. In support of this, McLaughlin et al (2004) showed that repeated administration of the KOP agonist U50488 in mice produces a long-lasting ( $>7$ day) tolerance to the antinociceptive effects of KOPs, paralleled by an increase in the phosphorylation state of a serine residue in the carboxyl terminal of the receptor. Phosphorylation of the rat KOP receptor at this particular site desensitizes the receptor (Appleyard et al, 1999; McLaughlin et al, 2003). Although many $G$ protein-coupled receptors are internalized after phosphorylation and desensitization, this process appears to be delayed in vivo for the KOP receptor as there are no changes in the overall receptor levels or in the levels of phosphorylated receptor for several days following KOP treatment (McLaughlin et al, 2004). Indeed, KOPs show poor internalization following agonist application (LiuChen, 2004), a step which promotes KOP receptor dephosphorylation and reactivation (McLaughlin et al, 2003).

The functional decreases in electrophysiology and KOP receptor G-proteins coupling could be due to the downregulation of KOP receptors levels. However, we found no change in KOP receptor protein level in either the NAc or the VTA. This finding contrasts a previous study (Turchan et al, 1998) using autoradiography in brain slices. The reason for this disparity is unclear, but it is not likely due to the assay differences between immunoblot and autoradiography, as we saw no difference in $\left[{ }^{3} \mathrm{H}\right]-\mathrm{U} 69593$ autoradiographic binding in the NAc between saline- and amphetamine-treated rats in NAc (data not shown).

It is curious that amphetamine does not produce a longlasting desensitization of KOP receptors in the VTA, despite evidence for dynorphin release in the midbrain in response to amphetamine (Bustamante et al, 2002). This specific mechanism underlying this difference between the VTA and the NAc is unclear, but may reflect regional differences in KOP receptor trafficking or differences in the trafficking of pre- and postsynaptic KOP receptors.

The loss of presynaptic inhibition is selective for the KOP receptor: MOP receptor-mediated inhibition in the NAc in response to a saturating dose of DAMGO is unaffected by acute amphetamine exposure (although we cannot rule out possible changes in the IC50 to DAMGO). Likewise, in our hands, bath application of DA inhibits fEPSPs following amphetamine exposure (data not shown). This is consistent with the finding that chronic cocaine administration produces an enhanced sensitivity to DA (Beurrier and Malenka, 2002). In addition, other investigators have found that presynaptic inhibition by endocannabinoids is unaffected by a single systemic injection of cocaine (Fourgeaud et al, 2004). Thus, presynaptic KOP receptor modulation of glutamate release in the NAc appears to be selectively lost following exposure to psychostimulants.

In contrast, several studies have observed postsynaptic changes at glutamatergic synapses in the NAc following psychostimulant exposure. For example, prolonged cocaine treatment (but not following a single injection) decreases the AMPA/NMDA receptor ratio in the NAc shell (Thomas et al, 2001). In addition, cocaine self-administration produces a postsynaptic decrease in the AMPA receptormediated fEPSP (Schramm-Sapyta et al, 2006). Finally, many studies have demonstrated changes in glutamate receptor subunit levels in the NAc following exposure to either cocaine or amphetamine (Lu et al, 1997, 1999; 
Churchill et al, 1999; Lu and Wolf, 1999). How these postsynaptic changes integrate with our observations to alter the function of the circuit remains to be determined.

While the changes in KOP receptor function observed in the NAc are robust, the changes in other synaptic properties were more subtle. We observed a significant increase in the paired-pulse ratio of EPSCs and a decrease in the short-term depression during bursts of stimuli following exposure to amphetamine. These changes are both consistent with a decrease in probability of release. However, it is also possible that these observed changes are independent of probability of release, for example, they could be due to alterations in the molecular mechanisms underlying shortterm plasticity (Rosenmund et al, 2003) or changes in shortterm plasticity that are independent of release probability (Casassus et al, 2005).

The changes in short-term plasticity observed in our study contrast several studies that did not observe significant changes in the paired-pulse ratio in mice that were either treated with or self-administered cocaine (Thomas et al, 2001; Fourgeaud et al, 2004; SchrammSapyta et al, 2006). This disparity most likely reflects differences between the pharmacological effects of cocaine and amphetamine. Alternatively, it may reflect differences between mice and rats. Finally, two of the studies measured the paired-pulse ratio using field potentials, as opposed to whole-cell EPSCs, and this method may be less sensitive to changes in release, particularly if those changes occur at only a subset of synapses.

Following systemic administration of either cocaine or amphetamine, expression levels of c-fos mRNA, an indirect measure of activity, are increased in substance P/dynorphin-containing MSNs (Johansson et al, 1994). At least a portion of these neurons projects to the VTA ( $\mathrm{Lu}$ et al, 1998). Thus, psychostimulants activate this direct pathway, causing the release of GABA as well as substance $P$ and dynorphin in the VTA. KOP receptor agonists decrease the c-fos staining in these neurons produced by injection of a D1 receptor agonist (Steiner and Gerfen, 1996). This indicates that KOP receptors on glutamate terminals in the NAc have a negative-feedback role, normally decreasing the excitability of substance P/dynorphin MSNs. The loss of this negative feedback would result in a hyperexcitability of these neurons, enhancing the release of dynorphin in downstream structures.

In the rat VTA, KOPs inhibit mesocortical, but not mesolimbic, DA neurons (Margolis et al, 2006). Acute amphetamine exposure does not alter KOP receptor function in the VTA. However, the loss of negative feedback in the NAc, along with the enhanced expression of preprodynorphin seen following amphetamine exposure (Wang et al, 1995; Turchan et al, 1998), will lead to increased KOP receptor activation within the VTA, resulting in reduced mesocortical DA. In fact, microdialysis studies in sensitized animals have observed this predicted decrease in MPFC DA (Sorg et al, 1997; Chefer et al, 2000) and impairments in cognition observed in amphetamine-sensitized animals can be reversed by D1 receptor agonists injected into the MPFC (Fletcher et al, 2005).

The current results are based on a moderately large dose of amphetamine (Grilly and Loveland, 2001) and caution should be exercised in extending these findings to other doses of amphetamine. For example, it is unclear whether low doses of amphetamine, such as those used to treat ADHD, sufficiently activate the KOP system to produce receptor desensitization. On the other hand, given the very slow recovery from desensitization, small amounts of receptor desensitization may build up over time with repeated dosing.

The observation that an effect of amphetamine administration can be mimicked by KOP receptor agonists appears paradoxical to several studies showing that KOP receptor agonists prevent many of the behavioral effects of amphetamine (Gray et al, 1999; Tzaferis and McGinty, 2001). However, these immediate effects of KOP receptor stimulation can be distinguished from their longer-lasting modulatory effects on the endogenous opioid system.

In support of this, although the behavioral effects of cocaine are inhibited by acute activation of KOP receptors, pretreatment with a KOP receptor agonist can enhance cocaine-conditioned place preference (McLaughlin et al, 2006). Ultimately, the behavioral effects of opioid receptors in relationship to drugs of abuse depend upon both when and where they are activated. The results here, showing a region-specific decrease in KOP receptor function, highlight this point, and provide insight into how the KOP-mediated behaviors can change with drug experience.

\section{ACKNOWLEDGEMENTS}

We thank S Nicola and E Margolis for helpful comments on the manuscript. This work was funded by National Institute on Drug Abuse awards DA-15686 (GH) and DA-15232 (JW), and by funds provided by the State of California for medical research on alcohol and substance abuse through the University of California, San Francisco.

\section{DISCLOSURE/CONFLICT OF INTEREST}

The authors have no conflicts of interest to declare.

\section{REFERENCES}

Anderson KD, Reiner A (1990). Extensive co-occurrence of substance $\mathrm{P}$ and dynorphin in striatal projection neurons: an evolutionarily conserved feature of basal ganglia organization. J Comp Neurol 295: 339-369.

Appleyard SM, Celver J, Pineda V, Kovoor A, Wayman GA, Chavkin C (1999). Agonist-dependent desensitization of the kappa opioid receptor by $\mathrm{G}$ protein receptor kinase and betaarrestin. J Biol Chem 274: 23802-23807.

Bals-Kubik R, Ableitner A, Herz A, Shippenberg TS (1993). Neuroanatomical sites mediating the motivational effects of opioids as mapped by the conditioned place preference paradigm in rats. J Pharmacol Exp Ther 264: 489-495.

Beurrier C, Malenka RC (2002). Enhanced inhibition of synaptic transmission by dopamine in the nucleus accumbens during behavioral sensitization to cocaine. J Neurosci 22: 5817-5822.

Bustamante D, You ZB, Castel MN, Johansson S, Goiny M, Terenius L et al (2002). Effect of single and repeated methamphetamine treatment on neurotransmitter release in substantia nigra and neostriatum of the rat. J Neurochem 83: 645-654.

Casassus G, Blanchet C, Mulle C (2005). Short-term regulation of information processing at the corticoaccumbens synapse. J Neurosci 25: 11504-11512. 
Chang HT, Kitai ST (1985). Projection neurons of the nucleus accumbens: an intracellular labeling study. Brain Res 347: 112-116.

Chefer VI, Moron JA, Hope B, Rea W, Shippenberg TS (2000). Kappa-opioid receptor activation prevents alterations in mesocortical dopamine neurotransmission that occur during abstinence from cocaine. Neuroscience 101: 619-627.

Churchill L, Swanson CJ, Urbina M, Kalivas PW (1999). Repeated cocaine alters glutamate receptor subunit levels in the nucleus accumbens and ventral tegmental area of rats that develop behavioral sensitization. J Neurochem 72: 2397-2403.

Conrad LCA, Pfaff DW (1976). Autoradiographic tracing of nucleus accumbens efferents in rat. Brain Res 113: 589-596.

Cornish JL, Kalivas PW (2000). Glutamate transmission in the nucleus accumbens mediates relapse in cocaine addiction. J Neurosci 20: RC89.

Everitt BJ, Wolf ME (2002). Psychomotor stimulant addiction: a neural systems perspective. J Neurosci 22: 3312-3320.

Fallon JH, Leslie FM, Cone RI (1985). Dynorphin-containing pathways in the substantia nigra and ventral tegmentum: a double labeling study using combined immunofluorescence and retrograde tracing. Neuropeptides 5: 457-460.

Fletcher PJ, Tenn CC, Rizos Z, Lovic V, Kapur S (2005). Sensitization to amphetamine, but not PCP, impairs attentional set shifting: reversal by a D1 receptor agonist injected into the medial prefrontal cortex. Psychopharmacology (Berl) 183: 190-200.

Fourgeaud L, Mato S, Bouchet D, Hemar A, Worley PF, Manzoni OJ (2004). A single in vivo exposure to cocaine abolishes endocannabinoid-mediated long-term depression in the nucleus accumbens. J Neurosci 24: 6939-6945.

Goldstein A, Naidu A (1989). Multiple opioid receptors: ligand selectivity profiles and binding site signatures. Mol Pharmacol 36: $265-272$

Gray AM, Rawls SM, Shippenberg TS, McGinty JF (1999). The kappa-opioid agonist, U-69593, decreases acute amphetamineevoked behaviors and calcium-dependent dialysate levels of dopamine and glutamate in the ventral striatum. J Neurochem 73: $1066-1074$.

Grilly DM, Loveland A (2001). What is a 'low dose' of d-amphetamine for inducing behavioral effects in laboratory rats? Psychopharmacology (Berl) 153: 155-169.

Hjelmstad GO (2004). Dopamine excites nucleus accumbens neurons through the differential modulation of glutamate and GABA release. J Neurosci 24: 8621-8628.

Hjelmstad GO, Fields HL (2001). Kappa opioid receptor inhibition of glutamatergic transmission in the nucleus accumbens shell. J Neurophysiol 85: 1153-1158.

Hjelmstad GO, Fields HL (2003). Kappa opioid receptor activation in the nucleus accumbens inhibits glutamate and GABA release through different mechanisms. J Neurophysiol 89: 2389-2395.

Hoffman AF, Lupica CR (2001). Direct actions of cannabinoids on synaptic transmission in the nucleus accumbens: a comparison with opioids. J Neurophysiol 85: 72-83.

Horan P, Taylor J, Yamamura HI, Porreca F (1992). Extremely long-lasting antagonistic actions of nor-binaltorphimine (nor-BNI) in the mouse tail-flick test. J Pharmacol Exp Ther 260: $1237-1243$

Johansson B, Lindstrom K, Fredholm BB (1994). Differences in the regional and cellular localization of $\mathrm{c}$-fos messenger RNA induced by amphetamine, cocaine and caffeine in the rat. Neuroscience 59: 837-849.

Jones DN, Holtzman SG (1992). Long term kappa-opioid receptor blockade following nor-binaltorphimine. Eur J Pharmacol 215: 345-348.

Kelley AE, Baldo BA, Pratt WE, Will MJ (2005). Corticostriatalhypothalamic circuitry and food motivation: integration of energy, action and reward. Physiol Behav 86: 773-795.
Liu-Chen LY (2004). Agonist-induced regulation and trafficking of kappa opioid receptors. Life Sci 75: 511-536.

Lu W, Chen H, Xue CJ, Wolf ME (1997). Repeated amphetamine administration alters the expression of mRNA for AMPA receptor subunits in rat nucleus accumbens and prefrontal cortex. Synapse 26: 269-280.

Lu W, Monteggia LM, Wolf ME (1999). Withdrawal from repeated amphetamine administration reduces NMDAR1 expression in the rat substantia nigra, nucleus accumbens and medial prefrontal cortex. Eur J Neurosci 11: 3167-3177.

Lu W, Wolf ME (1999). Repeated amphetamine administration alters AMPA receptor subunit expression in rat nucleus accumbens and medial prefrontal cortex. Synapse 32: 119-131.

Lu XY, Ghasemzadeh MB, Kalivas PW (1998). Expression of D1 receptor, D2 receptor, substance $\mathrm{P}$ and enkephalin messenger RNAs in the neurons projecting from the nucleus accumbens. Neuroscience 82: 767-780.

Margolis EB, Hjelmstad GO, Bonci A, Fields HL (2003). Kappaopioid agonists directly inhibit midbrain dopaminergic neurons. J Neurosci 23: 9981-9986.

Margolis EB, Lock H, Chefer VI, Shippenberg TS, Hjelmstad GO, Fields HL (2006). Kappa opioids selectively control dopaminergic neurons projecting to the prefrontal cortex. Proc Natl Acad Sci USA 103: 2938-2942.

McFarland K, Kalivas PW (2001). The circuitry mediating cocaineinduced reinstatement of drug-seeking behavior. J Neurosci 21: 8655-8663.

McFarland K, Lapish CC, Kalivas PW (2003). Prefrontal glutamate release into the core of the nucleus accumbens mediates cocaineinduced reinstatement of drug-seeking behavior. J Neurosci 23: 3531-3537.

McLaughlin JP, Land BB, Li S, Pintar JE, Chavkin C (2006). Prior activation of kappa opioid receptors by U50,488 mimics repeated forced swim stress to potentiate cocaine place preference conditioning. Neuropsychopharmacology 31: 787-794.

McLaughlin JP, Myers LC, Zarek PE, Caron MG, Lefkowitz RJ, Czyzyk TA et al (2004). Prolonged kappa opioid receptor phosphorylation mediated by G-protein receptor kinase underlies sustained analgesic tolerance. J Biol Chem 279: 1810-1818.

McLaughlin JP, Xu M, Mackie K, Chavkin C (2003). Phosphorylation of a carboxyl-terminal serine within the kappa-opioid receptor produces desensitization and internalization. J Biol Chem 278: 34631-34640.

Nestler EJ (2004). Molecular mechanisms of drug addiction. Neuropharmacology 47(Suppl 1): 24-32.

Phillipson OT (1979). Afferent projections to the ventral tegmental area of Tsai and interfascicular nucleus: a horseradish peroxidase study in the rat. J Comp Neurol 187: 117-143.

Rosenmund C, Rettig J, Brose N (2003). Molecular mechanisms of active zone function. Curr Opin Neurobiol 13: 509-519.

Schramm-Sapyta NL, Olsen CM, Winder DG (2006). Cocaine selfadministration reduces excitatory responses in the mouse nucleus accumbens shell. Neuropsychopharmacology 31: 1444-1451.

Shippenberg TS, Chefer VI, Zapata A, Heidbreder CA (2001). Modulation of the behavioral and neurochemical effects of psychostimulants by kappa-opioid receptor systems. Ann NY Acad Sci 937: 50-73.

Shippenberg TS, Elmer GI (1998). The neurobiology of opiate reinforcement. Crit Rev Neurobiol 12: 267-303.

Sorg BA, Davidson DL, Kalivas PW, Prasad BM (1997). Repeated daily cocaine alters subsequent cocaine-induced increase of extracellular dopamine in the medial prefrontal cortex. J Pharmacol Exp Ther 281: 54-61.

Steiner H, Gerfen CR (1996). Dynorphin regulates D1 dopamine receptor-mediated responses in the striatum: relative contributions of pre- and postsynaptic mechanisms in dorsal and ventral striatum demonstrated by altered immediate-early gene induction. J Comp Neurol 376: 530-541. 
Steiner H, Gerfen CR (1998). Role of dynorphin and enkephalin in the regulation of striatal output pathways and behavior. Exp Brain Res 123: 60-76.

Sulzer D, Sonders MS, Poulsen NW, Galli A (2005). Mechanisms of neurotransmitter release by amphetamines: a review. Prog Neurobiol 75: 406-433.

Swanson LW (1982). The projections of the ventral tegmental area and adjacent regions: a combined fluorescent retrograde tracer and immunofluorescence study in the rat. Brain Res Bull 9: 321-353.

Thomas MJ, Beurrier C, Bonci A, Malenka RC (2001). Long-term depression in the nucleus accumbens: a neural correlate of behavioral sensitization to cocaine. Nat Neurosci 4: 1217-1223.

Todtenkopf MS, Marcus JF, Portoghese PS, Carlezon Jr WA (2004). Effects of kappa-opioid receptor ligands on intracranial self-stimulation in rats. Psychopharmacology (Berl) 172: 463-470.

Turchan J, Przewlocka B, Lason W, Przewlocki R (1998). Effects of repeated psychostimulant administration on the prodynorphin system activity and kappa opioid receptor density in the rat brain. Neuroscience 85: 1051-1059.
Tzaferis JA, McGinty JF (2001). Kappa opioid receptor stimulation decreases amphetamine-induced behavior and neuropeptide mRNA expression in the striatum. Brain Res Mol Brain Res 93: 27-35.

Vanderschuren LJ, Schmidt ED, De Vries TJ, Van Moorsel CA, Tilders FJ, Schoffelmeer AN (1999). A single exposure to amphetamine is sufficient to induce long-term behavioral, neuroendocrine, and neurochemical sensitization in rats. J Neurosci 19: 9579-9586.

Wang JQ, Smith AJ, McGinty JF (1995). A single injection of amphetamine or methamphetamine induces dynamic alterations in c-fos, zif/268 and preprodynorphin messenger RNA expression in rat forebrain. Neuroscience 68: 83-95.

You ZB, Herrera-Marschitz M, Nylander I, Goiny M, O'Connor WT, Ungerstedt $U$ et al (1994). The striatonigral dynorphin pathway of the rat studied with in vivo microdialysis - II. Effects of dopamine D1 and D2 receptor agonists. Neuroscience 63: 427-434.

Yuan XR, Madamba S, Siggins GR (1992). Opioid peptides reduce synaptic transmission in the nucleus accumbens. Neurosci Lett 134: $223-228$. 